\title{
Responding to the crisis in sub-Saharan Africa: the role of nutrition
}

\author{
Mickey Chopra ${ }^{1, *}$ and lan Darnton-Hill ${ }^{2}$ \\ 'Director, Health Systems Research Unit, Medical Research Council of South Africa, School of Public Health, \\ University of the Western Cape, Cape Town, South Africa: ${ }^{2}$ Senior Adviser, Nutrition Section, United Nations \\ Children's Fund, New York, NY, USA
}

Submitted 4 August 2005: Accepted 11 January 2006

\begin{abstract}
In the chapter dealing with education and health, the report of the influential Commission for Africa prioritises basic health systems, HIV/AIDS, malaria and tuberculosis. In contrast, nutrition is given less than half a page and is reduced to parasite control and micronutrient support. Such neglect of nutrition is hard to understand in the context of increasing hunger and malnutrition across the continent. Sub-Saharan Africa is the only region in the world where the proportion of underweight children has stagnated and the absolute numbers have actually increased in the last decade. It has been pointed out that if current trends continue sub-Saharan Africa will achieve the Millennium Development Goal for child mortality around 2115 - one century after the target date. Quite clearly those concerned with nutrition need to more powerfully advocate the role of nutrition in lifting Africa out of the spiral of poverty. The present paper argues that to achieve this requires an understanding not just of the critical role of nutrition for health and development (both individual and national), but also of how recent global changes are interacting with changes in food production and supply, other determinants of maternal and child health, and the role and capacity of the state to tackle malnutrition in Africa. It concludes by suggesting some responses that nutritionists could now be making.
\end{abstract}

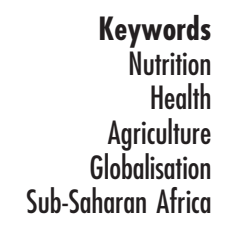

Unprecedented attention is now being given to the plight of sub-Saharan Africa (SSA). The recent release of the influential Commission for Africa Report has initiated significant new policies aimed at alleviating poverty across the continent ${ }^{1}$. The attention paid at the recent G8 Meeting in Gleneagles, UK, further highlighted the needs of the subcontinent. In its chapter dealing with education and health, the Report prioritises basic health systems, HIV/ AIDS, malaria and tuberculosis. In contrast, nutrition is given less than half a page and reduced to parasite control and micronutrient support. Such neglect of nutrition is hard to understand in the context of increasing hunger and malnutrition across the continent. Moreover, worldwide approximately $15 \%$ of the global burden of diseases is attributed to the combined effects of child and maternal underweight or micronutrient deficiencies ${ }^{2}$.

SSA is the only region in the world where the absolute number and proportion of undernourished children have increased in the last decade. Eastern Africa is the subregion experiencing the largest increases in numbers of underweight children - projected to increase by 36\% from 1990 to 2005. Findings for stunting and wasting are similar $^{3}$. Undernutrition is the underlying cause of over half of all child deaths ${ }^{4}$. Currently, 4.8 million children in SSA die before 5 years of age every year. With one-fifth of the world's births, SSA currently accounts for $45 \%$ of child deaths. It is also the only region of the world where the number of child deaths is rising. Of 45 countries in the region, 10 countries - including Kenya, Zambia and Zimbabwe - have gone backwards since 1990. Another 19 countries are progressing so slowly that the Millennium Development Goals (MDGs) target on child mortality will be missed by more than 35 years ${ }^{5}$. It has been pointed out that if current trends continue, SSA will achieve the MDG for child mortality around 2115 - one century after the target date. And yet, still it warrants only half a page in Africa's major concerns. The first MDG, on halving poverty and hunger, is similarly making little progress on the nutrition (or non-income) part of the target. It is overwhelmingly clear that the persistence of hunger and malnutrition has serious short-term consequences for national budgets, and serious long-term implications for national development and economic growth ${ }^{6,7}$.

Even more depressing is the lack of progress for women. Only three out of the 10 African countries with maternal nutrition data showed a decline in the prevalence of severe maternal undernutrition (body mass index $<16 \mathrm{~kg} \mathrm{~m}^{-2}$ ) in the last decade ${ }^{3}$. In SSA, which in itself accounts for half of the developing world's maternal deaths with one in every 100 live births resulting in the mother's death ${ }^{8}$, a woman is 100 times more likely to die in pregnancy and childbirth than in a high-income country ${ }^{8}$. 
At the same time, urban poor women have levels of obesity and diabetes as great as those in the USA?

There is now an impressive body of evidence documenting the significant reduction in intellectual and physical growth caused by both macronutrient and micronutrient deficiencies $^{10,11}$. Such high levels of undernutrition are undoubtedly undermining other investments in health and education, which are, in themselves, totally inadequate. The data are there, so why is the advocacy so ineffective?

Perhaps one of the reasons for the lack of urgency related to malnutrition is to do with the unprecedented global expansion in food production and trade. Food production is at an all-time high - having doubled in the past 40 years, as has production per capita. There is now more than enough food to feed everybody on the planet. The global value of trading in food grew from \$US 224 billion in 1972 to \$US 438 billion in 1998; food now constitutes 11\% of global trade, a percentage higher than that of fuel ${ }^{12}$. For many, the benefits from such an expansion in food trade have been great. Globally, food prices have fallen by $50 \%$ and are at an all-time low (closely related to the huge US and European subsidies). Supermarket shelves across the globe are now crammed with a cornucopia of different foods from different regions of the world. Cut flowers and exotic fruits are available throughout the year, irrespective of the season, in wealthy countries. However, as the data presented earlier illustrate, there a great many more people who are not benefiting from this state of affairs - often from the very countries exporting flowers and fruit.

Quite clearly those concerned with nutrition need to more powerfully advocate the role of nutrition in lifting Africa out of the spiral of poverty ${ }^{13}$. To achieve this requires an understanding not just of the critical role of nutrition for health and development (both individual and national), but also of how recent global changes are affecting the nutritional status of women and children. An obvious starting point would be the impact on agriculture and the availability of food $-70 \%$ of the African population still depends on agriculture for food, income and employment. But the analysis must also take into consideration the interaction of globalisation and other determinants of maternal and child health, such as general health and education systems, and the role and capacity of the state to tackle malnutrition in Africa ${ }^{14}$. The 1990 United Nations Children's Fund (UNICEF) framework of immediate, underlying and basic factors is implicitly used ${ }^{7}$. Whereas there has been a great deal of attention to the role of undernutrition in child survival, most has focused on the immediate and underlying (proximal) causes and less on the more distal causes. Not addressing these may well make local interventions unsustainable.

\section{Globalisation, agriculture and food}

The depression of crop prices no longer makes agriculture in Africa an attractive proposition for governments or donors. US subsidies to their own agro-industry mean that major crops are put on the international market at well below their production costs: wheat by an average of $43 \%$ below the cost of production, soyabeans at $25 \%$ below, cotton at $61 \%$ below and rice at $35 \%$ below $^{15}$. Subsidies to farming in the Organization for Economic Cooperation and Development (OECD) countries, which totalled \$US 311 billion in 2001 (or US\$ 850 million per day), displaces farming in the developing countries, costing the world's poor countries about \$US 24 billion per year in lost agricultural and agro-industrial income ${ }^{16}$.

The shift away from national food sufficiency is a global phenomenon - international cereal, wheat and rice imports have more than tripled since the 1960s. The fastest growth of food imports has occurred in Africa, which accounted for 18\% of world imports in 2001 - up from 8\% just 15 years previously ${ }^{17}$. This has occurred partly because of a decline in agricultural and rural investment in Africa. For years, public investment in agriculture has been falling, not rising. Globally, in countries with more than $35 \%$ of their population suffering food insecurity, agricultural investment in 1992 was $6.8 \%$ of gross domestic product and declined to $4.9 \%$ in $1996^{16}$. World Bank lending for agriculture declined dramatically from about $31 \%$ of its total lending portfolio in 1979-1981 to less than $10 \%$ in 1999-2000. Similarly, from fiscal years 1992 to 1997, the US Agency for International Development reduced its funding to agriculture programmes in SSA from $10 \%$ of its total obligations to only $5 \%$. It cut agricultural investments in SSA during that period by $57 \%$, to about \$US 80 million. By 2000, African agriculture received less US development assistance than any other sector ${ }^{18}$.

This has led to a continuing decline in agricultural productivity. Agricultural productivity per worker for the region as a whole has fallen by about $12 \%$ since 1980. Growth in agricultural output has arisen mostly from expansion in the area under cultivation, encroaching onto fallow lands and leading to significant reductions in soil fertility ${ }^{18}$. Significantly, the yields of most important food grains, tubers and legumes in most African countries are no higher today than in 1980. Average annual cereal yields are $1120 \mathrm{kgha}^{-1}$, compared with $2067 \mathrm{kgha}^{-1}$ for the world as a whole ${ }^{19}$. Only about $4.2 \%$ of land under cultivation in Africa is irrigated. This compares with 14\% in Latin America and the Caribbean, a region with similar population densities and resource endowments. Fertilizer application is $15 \%$ lower today than in 1980 . The number of tractors per worker is 25\% lower than in 1980 and the lowest in the world. Africa's share of total world agricultural trade fell from $8 \%$ in 1965 to $3 \%$ in $1996^{20}$.

Instead of growing basic food crops that compete with subsidised crops from the North, African countries are being encouraged to focus on 'high-value' agricultural products such as fresh flowers and exotic fruits for export. At least five important consequences of the trend towards 
exporting agricultural products are relevant, as detailed below.

\section{Commercialisation of farming}

The higher quality control and infrastructure requirements for the international market mean that high levels of capital investment and economies of scale are needed. Large commercial farms are consolidating their dominance across many countries in the region. South Africa, for example, has an active land redistribution programme that is focused upon increasing the number of smallholdings, yet the average size of farms has actually increased in the last five years. A minority of the country's 45000 farmers own $86 \%$ of all agricultural land, $50 \%$ of farmers own $6 \%$ and just over a quarter (26\%) of farmers earn $81 \%$ of agricultural income ${ }^{21}$. This trend is being exacerbated by the growing dominance in the local retail market of supermarkets that now sell more than $70 \%$ of retailed food but source $98 \%$ of this food from commercial farms.

\section{Increased export crops}

There is significant shift in the use of land (especially the most fertile) from being used for growing food for local consumption towards horticulture and growing export crops. This is well documented in Latin America. In Chile the total area under local food crops fell by $30 \%$ just three years after liberalisation. In Brazil the soyabean export crop increased from 1.4 million ha in 1970 to more than 15 million ha in $2000^{22}$.

\section{Reduced rural investment}

Increased growing of food crops for export is redirecting the already small investments in rural areas towards expensive infrastructure projects designed to provide rapid road connection between commercial farms and airports, ports and other points from which produce can be distributed to international markets. It is also undermining other support mechanisms for small farmers such as agricultural research.

\section{Reduced investment in agricultural research}

The annual growth rate in funding for agricultural research declined from $2.0 \%$ in the 1970 s to only $0.8 \%$ in the 1990 s. As a consequence, average spending per scientist declined by about half between 1971 and 2000. This is being partially replaced by private funding with increasing emphasis upon commercial applications such as biotechnology ${ }^{16}$.

\section{Increased economic vulnerability}

Increasing reliance upon exports makes countries in the region especially vulnerable to changes in agricultural policies in OECD countries, especially to those from the EU, which accounts for $50 \%$ of agricultural exports. The recent promises to reduce agricultural subsidies may be at the expense of the special treatment that many agricultural exports from this region have in the EU. For example, the recent move to reduce the price of sugar within the EU is calculated to cost over \$US 250 million to African countries and Caribbean sugar exporters ${ }^{14}$.

\section{Increasing inequality}

These changes in the trade and production of food are reshaping the African landscape. Across the continent people are being driven from their smallholdings towards the cities. Inequalities are increasing. Even middle-income countries such as South Africa are not immune to these processes. More than $60 \%$ of the population now lives in urban centres. The last five years alone have seen more than 3 million people ( $7 \%$ of the population) migrate from rural to urban areas. From 1996 to 2001 unemployment amongst the poorer black African population increased from $42.5 \%$ to over $50 \%$, compared with a rise from $4.6 \%$ to $6.3 \%$ in the better-off white population ${ }^{23}$. However, income inequalities are rising highest within the black population as an urban élite takes advantage of the new opportunities $^{24}$.

These inequalities help to explain the persisting high levels of undernutrition in South Africa despite 10 years of economic growth and food surpluses. Stunting rates are six times higher in the poorest quintile compared with the richest (38\% vs. 6\%). Mothers residing in the predominantly rural and African provinces, such as the Eastern Cape, are nine times more likely not to have any skilled attendant during childbirth (18\% vs. $2 \%$ ) than those in more urbanised and racially mixed provinces such as the Western Cape. Their families are also 2.5 times (83\% vs. $31 \%$ ) more likely to be food-insecure ${ }^{25}$, four times (31\% vs. $7.5 \%)$ less likely to have access to safe sanitation, and 10 times (35\% vs. 3\%) more likely to be using indoor pollutants such as firewood for cooking and heating ${ }^{26}$.

\section{Globalisation and other sectors}

Parallel but intimately connected processes are occurring in sectors that also influence maternal and child health and nutrition. These include the following.

\section{Inadequate investment}

In particular, there has been inadequate spending on health and nutrition, and related sectors such as education, by national governments - at least partly because of lack of national resources. The limited overall effect and sustainability of short-term disease-specific approaches such as a focus on the private sector and programmes independent of health systems have been demonstrated, and underline the need for strengthening health systems as a basis for sustainable gains ${ }^{27}$. Of the measurable health-related goals, the world is further from achieving the one for child mortality - a two-thirds reduction by 2015 - than from any other ${ }^{28}$. The goal to reduce poverty, 
of which the non-income target indicator is undernutrition in children, is also far behind target. That so many countries around the world will fall far short of the MDGs in the 10 years to 2015 points to an urgent need to change course $^{5}$.

\section{Ill-advised external advice and donor-driven priorities}

The lack of investment or inappropriate investment has been encouraged at times by ill-advised external advice the most obvious being the structural adjustment policies of the World Bank in the 1980s - but continue with the fee-for-service push of more recent years ${ }^{29}$. The health systems in many African countries are near collapse ${ }^{29-31}$. Another area has been the pressure by advice or by funding flows from bilateral and multilateral aid. For low-income SSA countries, international policy and external financial support are closely intertwined - 'either directly, through policy conditions linked to external aid, or indirectly, from advice, assistance, or support that particular donors offer ${ }^{29}$. This has not infrequently resulted in vertical programmes, often at the expense of community-driven needs and primary health care. The funding and investments in micronutrient deficiencies prevention and control programmes, while based on good evidence for the intervention itself, is one obvious example. Emphasis on new vaccines is another. How to address the emerging epidemic of non-communicable diseases, while not a priority for many countries of SSA, is also needed in future planning. An analysis by Ezzati et al. ${ }^{2}$ indicates that cardiovascular disease risks such as obesity and diabetes are 'expected to systematically shift to lowincome and middle-income countries, and, together with the persistent burden of infectious diseases, further increase global inequalities'. They suggest therefore that preventing obesity should be a priority from the early stages of economic development ${ }^{2}$.

\section{Undermining of bealth and nutrition systems and education}

Education of women is a powerful weapon against malnutrition: increased knowledge and skills enable women to earn higher incomes and thus enhance household food security, and education improves the quality of day-to-day care women give to their children ${ }^{32}$. The positive association between maternal education and health and nutritional status of children is well established $^{32,33}$. Educated women have fewer children, seek medical attention sooner for themselves and their children, and provide better care and nutrition for their children $^{34}$. One important outcome of globalisation is the increased brain drain of African health workers that is further undermining the health system. Many African countries are being left with less than 500 doctors each, as health-care staff are recruited by affluent countries that find it easier and cheaper to recruit from abroad than to train to their own citizens ${ }^{35}$. Ghana, with a population of
20 million, has only 1500 doctors, and more than twothirds of young Ghanaian doctors leave the country within three years of graduation. In Mozambique, a nation of similar size, there are just 500 doctors $^{35}$.

\section{Lack of research into diseases of the poor}

There is considerable evidence of this inequity, and there is some effort to improve on this. However, as long as reliance on the private sector is the main drive for pharmaceutical innovations, areas of the world that offer little ability to buy drugs will be disadvantaged, as companies have little incentive to fund research for drugs that are unlikely to adequately return the investment with a profit ${ }^{36}$. Doyal ${ }^{37}$ has explored the problem of gender and the 10/90 gap (10\% investment on research of the diseases affecting $90 \%$ of the world's poorer people) in health research. Similarly, the biotechnology industry, including that of genetically modified foods, will not necessarily deliver innovation to those who need it most ${ }^{38}$. The inadequate inputs into research into African agriculture and horticulture have been noted earlier ${ }^{16}$.

\section{Poor governance}

Poor governance, corruption and internal war are often cited as major causes for the lack of progress in SSA. Indeed, the Food and Agriculture Organization of the United Nations states that armed conflict is now the leading cause of hunger around the world; the effects of HIV and AIDS and climate were not far behind in the same report to the Committee on World Food Security ${ }^{39}$. The role of major powers, for both ideological and trade reasons, has been a major factor in most of the longerrunning civil wars in Africa over the last three decades, although there are some more encouraging trends currently. The increasing use of mercenaries in SSA does not help the process.

\section{Making a response}

In considering appropriate responses, it is important to appreciate how the capacity and power of national states, public agencies and communities are being seriously attenuated by the processes of globalisation ${ }^{9,29}$. Free trade and globalisation have increased the power and control of the food-supply chain by a small number of massive transnational corporations (TNCs). For example, six TNCs account for $85 \%$ of world trade in grain, eight account for $60 \%$ of global coffee sales, seven for $90 \%$ of the tea consumed in the North, three for $83 \%$ of the world trade in coca and three for $80 \%$ of bananas ${ }^{21}$. One TNC, Cargill, controls $80 \%$ of grain distribution throughout the world through its ownership of grain elevators, rail links, barges and ships ${ }^{40}$. The situation in the agrochemical sector is the same: 10 agrochemical companies control 81\% of the \$US 29 billion global agrochemical market. Four TNCs now own nearly $45 \%$ of all patents for staple crops such as rice, 
maize, wheat and potatoes ${ }^{41}$. In South Africa, Monsanto completely controls the national market for genetically modified seed, $60 \%$ of the hybrid maize market and $90 \%$ of the wheat market ${ }^{20}$.

The concentration of power and control in the hands of a few TNCs is accelerating with trade liberalisation. For example, the local exporters' share of the Côte d'Ivoire cocoa export market declined from 43\% in 1997-1998 to less than $10 \%$ in 1999-2000 following the dramatic liberalisation of the sector in 1999. Three multinational processors now dominate the market: ADM, Cargill and Barry Callebaut ${ }^{42}$.

The rising power of TNCs has been accompanied by deliberate reduction of the capacity and role of the state through structural adjustment programmes. Often this contributes directly to increasing rural poverty and undernutrition. For example, in an attempt to stimulate greater involvement by the private sector, the World Bank, through its structural adjustment reforms, replaced the Zambian grain marketing authority with the much smaller Food Reserve Agency. However, a lack of infrastructure has made it uneconomical for private traders to do business in remote areas, and people have been left with no access to markets on which to sell their produce or buy inputs. An independent International Monetary Fund evaluation found that liberalisation of the state marketing board contributed to a $30 \%$ increase in rural poverty between 1991 and $1994^{43}$.

\section{What are we to do?}

Africa cannot afford to waste its greatest resource: the intellectual power of its people. This is what is happening where low birth weight is common, where children fail to achieve their full potential growth, where micronutrient deficiencies permanently damage the brain, and where anaemia and short-term hunger limit children's performance at school. Improvement in the iron status of affected populations, for example, can raise national productivity levels by $20 \%{ }^{44}$.

The work by tobacco researchers - showing the direct relationship between trade liberalisation and increasing tobacco consumption in developing countries, and the strategies being used by tobacco companies - was critical in the formulation of the Framework Convention on Tobacco Control that is forming the basis for comprehensive tobacco control strategies across many countries. The pioneering work of nutritionists in highlighting the role of formula milk manufacturers led to the Code on the Marketing of Breastmilk Substitutes. We face a similar challenge in documenting the impact of globalisation on food systems, livelihoods, inequalities and hence nutri$\operatorname{tion}^{45}$.

Information from robust nutritional surveillance systems in Indonesia and Bangladesh has been used to document the impacts of economic crises and rice prices on the most vulnerable ${ }^{46}$ and to evaluate the effectiveness of state strategies. This in turn is raising the profile of nutrition in these countries. As noted in a different geographic context: '... improvements in health [and nutrition] cannot be expected from health reform or promotion alone ... the real improvements in health have come from political and economic reform, ${ }^{47}$. An analysis of health financing in Nepal concluded that policies to subsidise fees would increase utilisation substantially ${ }^{48}$, and this is likely to be true of poorly resourced systems everywhere ${ }^{29}$. Strategies must explicitly address "not only the poor and marginalised, but inequity - the gap itself ${ }^{29}$. Through the establishment of similar surveillance systems and partnering with progressive development academics and activists, nutritionists could play an important role in providing the evidence for policy change. Encouraging signs of reengagement include the release of the World Bank policy document on repositioning nutrition as central to development ${ }^{49}$ and the UNICEF Progress for Children update on the progress (or lack of it in at least 16 African countries) towards achieving the second, non-income target of the first $\mathrm{MDG}^{50}$.

African countries are not in the position of China or India in being able to resist the monumental global changes. Multilateral collective strategies, especially the development of international standards, are essential in protecting and promoting the public's health in the face of threats associated with globalisation. We have previously outlined the scope of binding and non-binding legal instruments in buttressing national governments' ability to control the trade and marketing of essential public health goods such as food ${ }^{51}$. Some nutritionists are now linking international obligations towards the right of people to be free from hunger and enjoy optimal nutrition to more binding legislation ${ }^{52}$. Previous experience with large food multinationals suggests that such a task will be resisted fiercely ${ }^{53}$.

But the nutrition community has a proud record of campaigning for the most vulnerable, whether it is protecting breast-feeding or providing objective dietary guidance. The untenable and immoral situation in Africa demands that nutritionists once again take the lead in placing the nutritional status of the most vulnerable at the centre of any discussions concerning globalisation, development and Africa.

\section{Acknowledgements}

The views expressed in this article are those of the authors and do not necessarily reflect those of the authors' organisations. Neither author has competing interests.

\section{References}

1 Commission for Africa Report. Our Common Interest. London: Penguin Books, 2005. Also available at http:// 
www.commissionforafrica.org/english/report/introduction. html. Accessed 25 July 2005.

2 Ezzati M, Lopez AD, Rodgers A, Van der Hoorn S, Murray CJL. Selected major risk factors and global and regional burden of disease. Lancet 2002; 360: 1347-60.

3 United Nations (UN) Administrative Committee on Coordination, Sub-committee on Nutrition. The 5th Global Nutrition Report. Geneva: UN System Standing Committee for Nutrition, 2004.

4 Black RE, Morris SS, Bryce J. Where and why are 10 million children dying every year? Lancet 2003; 361: 2226-34.

5 United Nations Development Programme (UNDP). Sub-Saharan Africa - The Human Costs of the 2015 'Business-as-Usual' Scenario. New York: Human Development Report Office, UNDP, 2005. Also available at http://hdr. undp.org/docs/events/Berlin/Background_paper.pdf. Accessed 13 July 2005.

6 World Food Programme. Ending Child Hunger Initiative. A discussion paper for the World Bank, UNICEF and WFP. Unpublished draft, 2005.

7 United Nations Children's Fund (UNICEF). Nutrition. In: State of the World's Children 1998. New York: UNICEF, 1998.

8 United Nations Development Programme (UNDP). Millennium Development Goals: A Compact among Nations to end Human Poverty. Human Development Report 2003. New York: UNDP, 2003.

9 Yach D, Kellogg M, Voute J. Chronic diseases: an increasing challenge in developing countries. Transactions of the Royal Society of Tropical Medicine and Hygiene 2005; 99: 321-4.

10 United Nations (UN) Millennium Project 2005, Task Force on Hunger. Halving Hunger: It Can Be Done. Report prepared for UN Millennium Project's report Investing in Development: A Practical Plan to Achieve the Millennium Development Goals. London: Earthscan, 2005. Also available at http://www.unmillenniumproject.org/documents/ Hunger-lowres-complete.pdf. Accessed 20 August 2005.

11 Grantham-McGregor S, Ani C. A review of studies on the effect of iron deficiency on cognitive development in children. Journal of Nutrition 2001; 131: 649S-66S.

12 Pinstrup-Andersen P, Babinard J. Globalisation and human nutrition: opportunities and risks for the poor in developing countries. African Journal of Food and Nutritional Sciences 2001; 1: 9-18.

13 Darnton-Hill I, Margetts BM, Chopra M, Nishida C, Bloem MW. Globalization, economics and nutrition - where are we going? Paper presented at the International Union of Nutritional Sciences Meeting, Durban, South Africa, 19-23 September 2005; 7 pp.

14 Chopra M. Food Security, Rural Development and Health Equity in Southern Africa. Discussion Paper No. 22. Harare: Regional Network for Equity in Health in Southern Africa, 2004.

15 Institute for Agriculture and Trade Policy (IATP). US Dumping on World Agricultural Markets. Minnesota: IATP, 2004. Also available at http://www.tradeobservatory.org/ library.cfm?refID=48538. Accessed 23 August 2004 .

16 Diao X, Diaz-Bonilla E, Robinson S. How Much Does it Hurt? Impact of Agricultural Polices on Developing Countries. Washington, DC: International Food and Policy Research Institute, 2003. Also available at http://www.ifpri.org/ media/trade/trade.pdf. Accessed 14 August 2004.

17 Food and Agriculture Organization of the United Nations (FAO). The State of Food Insecurity in the World 2003. Rome: FAO, 2003.

18 Beintema N, Stads G-J. Investing in Sub-Saharan African Agricultural Research: Recent Trends. 2020 Conference Brief 8. Washington, DC: International Food and Policy Research Institute, 2004. Also available at http://www.ifpri.org/pubs/ ib/ib24.pdf. Accessed 15 May 2005.
19 Devereux S. Transfers and safety nets. In: Devereux S, Maxwell S, eds. Food Security in Sub-Saharan Africa. London: ITDG Publishing, 2001.

20 World Bank. From Action to Impact. Discussion Paper, the Africa Region's Rural Strategy Rural Development Operations. New York: World Bank, 2002.

21 Nieuwoudt L, Groenewald J. The Challenge of Change: Agriculture, Land and the South African Economy. Durban: University of Natal Press, 2003.

22 Madeley J. Food for All. The Need for a New Agriculture. London: Zed Books, 2002.

23 Statistics South Africa. The People of South Africa Population Census, 2001. Census in Brief. Pretoria: Statistics South Africa, 2001. Also available at http://www.statssa.gov.za/ census2001/census2001.htm. Accessed 20 August 2004.

24 United Nations Development Programme (UNDP). South Africa: Human Development Report 2000 [online], 2000. Available at http://www.undp.org.za/sahdr2000/hdr. contents.pdf. Accessed 25 March 2004.

25 Labadarios D, ed. The National Food Consumption Survey (NFCS): Children aged 1-9 years, South Africa. Pretoria: National Department of Health, 1999.

26 Statistics South Africa. October Household Survey 1999. Statistical Release P0317 [online], 2004. Available at http:// www.statssa.gov.za/Statistical_releases/Statistical_releases. htm. Accessed 20 July 2005.

27 Sachs JD. Macroeconomics and Health: Investing in Health for Human Development. Geneva: World Health Organization, 2001.

28 United Nations Children's Fund (UNICEF). Progress for Children: A Child Survival Report Card, Volume 1. New York: UNICEF, 2004; 21 pp. Available at http://www.unicef.org/ publications/files/29652L01Eng.pdf. Accessed 25 August 2005.

29 United Nations (UN) Millennium Project. Who's got the Power? Transforming Health Systems for Women and Children. Summary version of the report of the Task Force on Child Health and Maternal Health. New York: UN, 2005; $24 \mathrm{pp}$.

30 Morris JT. Africa's food crisis as a threat to peace and security. Statement of the Executive Director to the Security Council. Rome: World Food Programme, 30 June 2005.

31 Dare L, Buch E. The future of health care in Africa. British Medical Journal 2005; 331: 1-2.

32 Smith LC, Ramakrishnan U, Ndiaye A, Haddad L, Martorell R. The Importance of Women's Status for Child Nutrition in Developing Countries. International Food Policy Research Institute (IFPRI) Research Report No. 131. Washington, DC: IFPRI/Department of International Health, Emory University, 2003.

33 Darnton-Hill I, Webb P, Harvey PWJ, Hunt JM, Dalmiya N, Chopra M, et al. Micronutrient deficiencies and gender: social and economic costs. American Journal of Clinical Nutrition 2005; 81(Suppl.): 1198S-205S.

34 Quisumbing AR, Haddad L, Peña C. Are Women Overrepresented among the Poor? An Analysis of Poverty in Ten Developing Countries. FCND Discussion Paper No. 115. Washington, DC: International Food Policy Research Institute, 2001; 66 pp.

35 Coombes R. Developed world is robbing African countries of health staff. British Medical Journal 2005; 330; 923 pp.

36 MacDonald R. Prioritising neglected diseases related to poverty. British Medical Journal 2005; 331: 12.

37 Doyal L. Gender and the 10/90 gap in health research. Bulletin of the World Health Organization 2004; 82: 162.

38 Brettingham M. Developing countries may not get benefits of GM food. British Medical Journal 2005; 331: 11.

39 Moszynski P. Armed conflict is a leading cause of hunger, says FAO. British Medical Journal 2005; 330: 1286. 
40 Kneen B. Invisible Giant. London: Pluto Press, 1996.

41 ActionAid. GM Crops - Going Against the Grain [online] 2003. Available at http://www.actionaidinternational.it/site/ download/GM\%20crops\%20-\%20Going\%20against $\% 20$ the $\%$ 20grain.pdf. Accessed 24 August 2004.

42 Yorley B. Food Inc. Corporate Concentration from Farm to Consumer. London: UK Food Group, 2004.

43 Lambrechts K, Barry G. Why is Southern Africa Hungry? The Roots of Southern Africa's Food Crisis. Policy Briefing. London: Christian Aid, 2003. Available at http://www.christianaid.org.uk/indepth/0307safrica/index.htm. Accessed 20 July 2005.

44 Hunt J. The potential impact of reducing global malnutrition on poverty reduction and economic development. Asia Pacific Journal of Clinical Nutrition 2005; 14: $10-38$.

45 Chopra M, Darnton-Hill I. Tobacco and obesity epidemics: not so different after all? British Medical Journal 2004; 328: $158-60$.

46 Torlesse H, Kiess L, Bloem MW. Association of household rice expenditure with child nutritional status indicates a role for macroeconomic food policy in combating malnutrition. Journal of Nutrition 2003; 133: 1320-5.

47 Godlee F. Untangling a skein of wool. British Medical Journal 2005; 331 (23 July). Available at http://bmj.bmjjournals.com/cgi/content/full/331/7510/0-9
48 Pokhrel S, Hidayat B, Flessa S, Sauerborn R. Modelling the effectiveness of financing policies to address underutilization of children's health services in Nepal. Bulletin of the World Health Organization 2005; 83: 338-44.

49 World Bank. Overview. In: Repositioning Nutrition as Central to Development. A Strategy for Large-scale Action. Directions in Development Paper. Washington, DC: World Bank, 2006.

50 United Nations Children's Fund (UNICEF). Progress on undernutrition. Draft prepared for Progress for Children: A Report Card on Nutrition, Number 4. New York: UNICEF, 2006.

51 Chopra M, Galbraith S, Darnton-Hill I. A global response to a global problem: the epidemic of overnutrition. Bulletin of the World Health Organization 2002; 80: 952-8.

52 United Nations (UN). Standing Committee on Nutrition (SCN). The human right to adequate food. UN SCN, 32nd Session, Brasilia, 14-18 March 2005. Available at www.unsystem.org/scn/. Accessed 30 July 2005.

53 Aguayo VM, Ross JS, Kanon S, Ouedraogo AN. Monitoring compliance with the International Code of Marketing of Breast milk Substitutes in West Africa. Findings from a multisite, cross-sectional survey in Togo and Burkina Faso. British Medical Journal 2003; 326: 127-30. 